\title{
Improving Genetic Attributes of Confectionary Traits in Peanut (Arachis hypogaea L.) Using Multivariate Analytical Tools
}

\author{
B. C. Ajay (Corresponding author) \\ University of Agricultural Sciences, Dharwad 580005, Karnataka, India \\ Present address: Crop improvement unit, Directorate of Groundnut Research, Junagadh 362001, Gujarat, India \\ Tel: 91-972-485-7946 E-mail: ajaygpb@yahoo.co.in \\ M. V. C. Gowda \\ University of Agricultural Sciences, Dharwad 580005, Karnataka, India \\ A. L. Rathnakumar \\ Crop improvement unit, Directorate of Groundnut Research, Junagadh 362001, Gujarat, India \\ E-mail: rathnakumar@nrcg.res.in \\ V. P. Kusuma \\ University of Agricultural Sciences, Dharwad 580005, Karnataka, India \\ R. Abdul Fiyaz
}

Division of Plant Breeding, ICAR Research Complex for North Eastern Hill Region

Barapani 793 103, Meghalaya, India

Tel: 91-986-331-5157 E-mail: genefiyaz@gmail.com

Prasanna Holajjer

Crop protection unit, Directorate of Groundnut Research

Junagadh 362001, Gujarat, India

E-mail: prasanna@nrcg.res.in

K. T. Ramya

Division of Plant Breeding, ICAR Research Complex for North Eastern Hill Region

Barapani 793 103, Meghalaya, India

Present address: Division of Genetics, Indian Agricultural Research Institute

Pusa campus, New Delhi 110 012, India

Tel: 91-901-378-6288Ｅ-mail: ramya.kt@gmail.com

G. Govindaraj

Social science unit, Directorate of Groundnut Research, Junagadh 362001, Gujarat, India

E-mail: govindaraj@nrcg.res.in

H. Prashanth Babu

University of Agricultural Sciences, Dharwad 580005, Karnataka, India

Present address: Division of Genetics and Plant Breeding

IARI, Regional Station, Karnal -132001 Haryana, India

Tel: 91-805-372-6449 E-mail: prashanthbabuh@gmail.com 
Received: August 22, 2011

doi:10.5539/jas.v4n3p247
Accepted: September 15, $2011 \quad$ Online Published: December 29, 2011

URL: http://dx.doi.org/10.5539/jas.v4n3p247

\begin{abstract}
Peanut is gaining importance more for its confectionery and nutritive values than for its oil content around the world. Improving confectionery qualities is an added advantage for farming community. Hence, in the present study, multivariate analytical tools were used to identify parents with complementary traits for using them in breeding programme. PCA revealed contribution of pod yield, 100 -seed weight, oil content, and O/L ratio towards variance. Pod yield was positively associated with 100 -seed weight, oil and protein contents. Oil content had weak association with protein content, oleic acid and O/L ratio. UPGMA clustering revealed grouping of cultivars based on origin and its area recommendation. Cultivars superior for yield (GPBD-4, M-28-2 and JL 24) and confectionery traits (S-230 and Dh-8) were identified. Strong positive relation of yield with confectionery traits indicates possibility of breeding high yielding confectionery grade cultivars. Multivariate analytical tools could be used to identify parents for location specific breeding for improvement of Confectionary traits.
\end{abstract}

Keywords: Cluster analysis, Confectionery traits, GT bi-plot, Molecular, PCA, Peanut

\title{
1. Introduction
}

Peanut (Arachis hypogaea L.) is an important oilseed crop around the world as well as in India. It is ranked as the second most important cultivated grain legume and the fourth largest edible oilseed crop in the world (Shilman et al., 2011). It is grown in more than 100 countries of which China (41 per cent), India (21 per cent), Nigeria ( 8 per cent), and the United States ( 7 per cent) are the largest producers (FAO, 2009). The crop is grown primarily for human consumption and it is a rich source of oil (40-50 per cent), proteins (20-50 per cent) and carbohydrates (10-20 per cent) (Belamkar et al., 2011).

Wide variation in productivity has been observed among various peanut growing states in India from $529 \mathrm{~kg} / \mathrm{ha}$ in the state of Bihar to $2286 \mathrm{~kg} / \mathrm{ha}$ in the state of Pondicherry (DAC, 2010). Though productivity in few states was above the world average $(1522 \mathrm{~kg} / \mathrm{ha}$ (FAO, 2009), but the national average $(1063 \mathrm{~kg} / \mathrm{ha})(\mathrm{DAC}, 2010)$ is very less. This low productivity of India could be attributed to few major peanut growing states like Karnataka and Andhra Pradesh. Hence, there is a need to increase the productivity in these regions at the earliest to improve national average. Though germplasm accessions are capable of raising genetic ceiling on improvement (Kannenberg and Falk, 1995), timescale may be too long (Upadhyaya et al., 2010). In this context, elite breeding lines are considered as best genetic resources because they contain combination of genetic traits that satisfies the marketplace (Troyer, 1990).

Improving the genetic potential of peanut for pod yield and oil content were the major objectives in most peanut improvement programs. Recent estimates revealed that only 49 per cent of its total produce is crushed for oil and the rest is used for sowing, direct consumption and export (SEA, 2010). Improving the confectionery qualities along with yield in low productivity regions may have significant impact on farming community. But, Quality requirement of peanut for confectionery purpose is different from those meant for oil extraction. Characters which are preferred for confectionery grade varieties are high protein and sugar, low oil and aflatoxin contamination, attractive seed size and shape, pink or tan seed colour and ease of blanching and high Oleic/linoleic acid (O/L) ratio (Nigam et al., 1989; Dwivedi and Nigam, 1995).

Hence, with the aim of improving confectionery attributes of the cultivars present study was aimed at understanding pattern of diversity among cultivars, optimum number of clusters involved and to identify suitable donor for further breeding programme using various multivariate analytical tools (UPGMA method of Clustering and PCA analysis). These tools are gaining importance to classify genotypes into different groups and to identify pattern of diversity among genotypes. The PCA reduces multivariate data to few principal axes, produces Eigen vectors for each axis and produces component scores for the characters (Sneath and Sokal, 1973). This study will also help in studying relation between various confectionery attributes which is important for developing confectionery grade cultivars.

\section{Material and Methods}

\subsection{Plant material and study area}

Experimental materials comprised of 17 cultivars of which 10 were location specific released for the state of Karnataka (Spanish improved, S-206, S-230, Dh-3-30, KRG-1, Dh-8, Dh-43, R-9251, Dh-40 and M-28-2) and rest had broad genetic base released for cultivation in different states of India (Table 1). The experiment was laid out in randomised complete block design (RCBD) with two replications at Botanical Garden of University of 
Agricultural Sciences, Dharwad Karnataka, India. The experimental site is located in the Northern Transitional Tract of Karnataka $\left(15^{\circ} 13^{\prime}\right.$ latitude of $75^{\circ} 07^{\prime}$ E longitudes; altitude, $678 \mathrm{~m}$ above mean sea level). Each cultivar was grown in a single row of $5 \mathrm{~m}$ length with a spacing of $30 \mathrm{~cm}$ between rows and $10 \mathrm{~cm}$ between plants. In each cultivar five competitive plants were randomly selected to record observations on quantitative traits namely number of primary branches, number of secondary branches, plant height $(\mathrm{cm})$, leaf length $(\mathrm{cm})$, leaf width $(\mathrm{cm})$, pod yield per plant (g) and 100-seed weight (g).

Since peanut is gaining importance as a snack food, improving nutritional qualities along with yield will have added benefits and may improve income of farming community. Hence confectionery qualities like oil content, protein content and fatty acid profile (palmitic acid, stearic acid, saturated fatty acid (SFA), oleic acid, linoleic acid and $\mathrm{O} / \mathrm{L}$ ratio) were also determined. Oil content was estimated by soxhlet method as given by Jambunathan et al., (1985). Five gram of peanut seeds were made into fine powder in a pestle and mortar and peanut meal was extracted with petroleum ether $\left(60-80^{\circ} \mathrm{C} \mathrm{bp}\right)$ for 5 hours in the soxhlet apparatus and subsequently ether was evaporated. Powder weight before and after extraction were recorded and difference between the two was expressed in terms of oil percentage. Protein content was determined by using defatted peanut meal as described by Lowry et al., (1951). Fatty acid profile of the 17 cultivars was studied using gas liquid chromatography following the method of AOCS (1999) involving two steps namely, preparation of fatty acid methyl esters (FAME) and gas liquid chromatography (GLC).

\subsection{RAPD assay}

The RAPD reactions were performed in $20 \mu$ volumes in $200 \mu \mathrm{l}$ PCR tubes (Tarson Pvt Ltd, India). The reaction mixture contained $15 \mathrm{ng}$ of template DNA, $1 \times$ amplification buffer, $10 \mathrm{mM}$ each of dCTP, dGTP, dATP, and dTTP, 5 pM primers and 1U Taq DNA polymerase (Bangalore Genei, Pvt. Ltd., India). The reactions were performed in a Master Cycler Gradient 5331 (Eppendorf version 2.30). The reaction had an initial denaturation step at $94^{\circ} \mathrm{C}$ for $5 \mathrm{~min}$, followed by 38 cycles of $94^{\circ} \mathrm{C}$ for $2 \mathrm{~min}, 36^{\circ} \mathrm{C}$ for $1 \mathrm{~min}, 72^{\circ} \mathrm{C}$ for $2 \mathrm{~min}$. The final extension step was at $72^{\circ} \mathrm{C}$ for $10 \mathrm{~min}$. The PCR products were mixed with $2 \mu \mathrm{l}$ of loading dye (bromophenol blue) and was separated on 1.4\% agarose gels (Sigma Aldrich, USA) at $5 \mathrm{~V} / \mathrm{cm}$ in $1 \times \mathrm{TBE}(89 \mathrm{mM}$ Tris-HCl, $89 \mathrm{mM}$ boric acid and $2 \mathrm{mM}$ EDTA, $\mathrm{pH} 8.0)$ buffer, stained with ethidium bromide $(0.75 \mu \mathrm{g} / \mathrm{ml})$ and visualized under UV trans-illuminator (UVI Tech, England) and the results were documented.

\subsection{Statistical analysis}

The data of different quantitative character were standardised by subtracting observations of each character by its mean value and subsequently dividing it by its standard deviation. This standardises the values of each character to mean zero and standard deviation of 1 . The standardised data were subjected to principal component analysis (PCA) (Pearson, 1901) and then scatter plot was developed for component 1 and 2. The PCs with eigen value $>1.0$ were considered as inherently more informative than any single variable alone (Kaiser, 1960). To display the genotype by trait two-way data on a bi-plot following formula was used (Yan and Rajcan, 2002)

$$
\underline{T_{i j}-T j}=\left(\lambda_{1} \zeta_{i 1} T_{j 1}+\lambda 2 \zeta_{i 2} T_{j 2}+T_{i j}\right) s_{j}
$$

where $T i j$ is the average value of genotype $i$ for trait $j, T j$ is the average value of trait $\mathrm{j}$ over all cultivars, $\mathrm{sj}$ is the standard deviation of trait $j$ among the genotype averages; $\zeta_{\mathrm{i} 1}$ and $\zeta_{\mathrm{i} 2}$ are the PC1 and PC2 scores, respectively, for genotype $i ; \mathrm{T}_{\mathrm{j} 1}$ and $\mathrm{T}_{\mathrm{j} 2}$ are the $\mathrm{PC} 1$ and $\mathrm{PC} 2$ scores, respectively for trait $j$ and ${ }_{\mathrm{ij}}$ is the residual of the model associated with the genotype $i$ in trait $j$. A genotype by trait (GT) bi-plot is constructed by plotting the PC1 scores against the PC2 scores for each genotype and trait. A dendrogram was also constructed for different quantitative character based on genetic distance matrix using standardised data by unweighed pair-group method using arithmetic averages (UPGMA) algorithm of Sneath and Sokal (1973) with Euclidean similarity measure. Pair-wise genetic similarity (Sij) between cultivars for RAPD assay was estimated using Dice similarity coefficient. Clustering was done using symmetric matrix of similarity coefficient. A dendrogram based on Sij values was constructed using clustering technique of unweighted pair group arithmetic mean (UPGMA) using SHAN module of NTSYSpc version 2.0 (Rohlf, 1998).

\section{Results}

\subsection{Varietal performance}

Performance of varieties for pod yield (pyl), 100-seed weight (twt), oil and protein content is presented Figure 1. Pod yield ranged from $6.07 \mathrm{~g}$ per plant (S 230) to $20.3 \mathrm{~g}$ (GPBD 4). Varieties Mutant 28-2, JL 24 were on par with GPBD-4 with 100-seed weight of more than 50g. Two varieties Dh-3-30 and Spanish improved were low oil genotypes with high protein. There was wide range in fatty acid profile among varieties. Oleic and linoleic acids represents 75 to 80 per cent of fatty acid profiles of groundnut followed by palmitic acid (10 to 17 per cent), stearic acid ( 0.56 to 7.93 per cent) and other fatty acid constitutes 2.3 to 10.5 per cent of total profile (Figure 2). Oleic acid ranged 35.0 per cent (Spanish improved and K-134) to 56.0 per cent (S 230). Linoleic acid ranged 
from 27.8 per cent (S-230) to $42.47 \%$ (Dh-3-30). R-9251(41.53\%) K-134 (40.55\%) and R 8808 (40.23\%) followed Dh-3-30. Apart from S 230 very low linoleic, palmitic and stearic acid was also observed in GPBD-4 $(28.82 \%)$.

\subsection{Cluster analysis}

Dendrogram obtained for various quantitative characters based on UPGMA (Figure 3) has grouped genotypes into three different clusters. Cluster 1 included six cultivars (JL-24, M-28-2, R-8808, ICGV-86590, Dh-40 and TAG-24) whereas cluster 2 (Spanish improved, Dh 3-30, S 206, KRG 1, K 134 and TMV-2) and cluster 3 (S 230 , Dh 43, Dh 8 and GPBD-4) had six and four cultivars respectively. Cultivar R-9251 did not group with any of the clusters. Mean, range and variance values for different qualitative and quantitative traits for all clusters based on UPGMA are presented in Table 2. Cultivars in cluster 3 were superior for oil and protein content, had more number of branches, less saturated fatty acids, high oleic acid and high $\mathrm{O} / \mathrm{L}$ ratio whereas for cultivars in cluster 1 average pod yield and 100 -seed weight was high.

\subsection{Principal component analysis (PCA)}

Results obtained from UPGMA cluster analysis was further corroborated by Principal component analysis (PCA) with correlation matrix. Five principle components accounted for approximately $84 \%$ variance. Breakdown of this cumulative variance revealed contribution of $35 \%$ and $19 \%$ for PC 1 and PC 2 respectively. Components 3 and 4 contributed $14 \%$ and $9 \%$ towards cumulative variance. Discriminating power of principle components as inferred from PCA analysis was high for PC 1(5.9) and low for PC 5 (1.3) (Table 3). First component (PC 1) that explained 35 per cent of variation significantly correlated with $(>0.7)$ oleic acid and $\mathrm{O} / \mathrm{L}$ ratio in positive direction and with leaf length, leaf width, palmitic acid, linoleic acid and saturated fatty acid in negative direction. Second component (PC 2) significantly correlates to pod yield, other unsaturated fatty acids and oil content. Components 3 and 4 (PC 3 to PC 5) correlated significantly to primary branches (-0.8) and protein content $(0.7)$ respectively. Hence, for developing confectionery grade varieties genotypes with high PC 1 and high PC 2 have to be selected which would intern would contribute complementary traits for developing high yielding confectionery traits.

Graphical plot of PC 1 vs. PC 2 (Figure 4) revealed that cultivars Spanish improved, K-134, KRG-1, Dh-3-30, S-206 and R-9251 were clustered together and they possessed low oleic, high linoleic acid, high saturated fatty acid and low O/L ratio. Cultivars R-8808, ICGV-86590, TAG-24 and Dh-40 derived through hybridization were grouped together and possessed approximately same amounts of oleic and linoleic acid in their profile. Cultivars GPBD-4 and S-230 with low saturated fatty acid (12.9\% and $12.7 \%$ respectively), high oleic $(48.5 \%$ and $55.8 \%)$, low linoleic acid (28.8\% and 27.8\%) and high O/L ratio (1.7 and 2.0) possessed high PC 2 values. Cultivar GPBD-4 was superior to $\mathrm{S} 230$ with respect to pod yield (20.3 and $6.1 \mathrm{~g} / \mathrm{plant}$ respectively).

\subsection{Molecular diversity}

Twenty primers on 17 cultivars generated a total of 145 amplified fragments, out of which 99 were polymorphic (Table 4). The polymorphism for primers ranged from 0 (OPA-15) to 100 per cent (OPC-03) with an overall average of 68.3 per cent. Number of amplified fragments ranged from 1 to 15 for a given primer. On an average, 7.3 bands per primer were amplified out of which 4.9 bands were polymorphic. Banding pattern of seventeen genotypes is presented in Figure 5. High polymorphism observed among the cultivars may be due to use of reported polymorphic primers (Subramanian et al., 2000; Dwivedi et al., 2001; Rajendraprasad, 2003; Vijay, 2003; Nagaraja Reddy et al., 2004; Pattanashetti, 2005). In contrast, Dwivedi et al., 2001 have reported low to moderate level of polymorphism ranging from 8.7 to 33.1 per cent among primers in twenty-six accessions including interspecific derivatives, land races and released cultivars. Based on the Dice Coefficients (Okuno et al., 1998) mean similarity indices for 17 cultivars ranged from 0.67 to 0.97 (mean 0.84) indicating that accessions had 84 per cent of their fragments in common thus indicating low level of diversity among the cultivars studied. The genotypes Dh-8 and ICGV-86590 were most diverse in comparison with other genotypes. The dendrogram, revealed two distinct clusters 'A' and 'B' at Sij of 0.85. Cluster B had R-8808, GPBD-4 and ICGV-86590 (Figure 6). All other varieties were grouped in cluster A. JL-24 and ICGV-86590 was found to span the extremes of the entire dendrogram with the remaining types distributed between them. Cluster B consisted of R-8808, GPBD-4 and ICGV-86590. They had at least one parent, which is not native to India. Cluster A had varieties, which were obtained either from selection of land races. So, the genetic similarity among varieties is high.

\section{Discussion}

\subsection{GT Bi-plot and trait relations}

Genotype by trait (GT) bi-plot can be used to (i) identify traits contributing to diversity, (ii) identify superior cultivars for different traits and (iii) to study interrelationships between traits. GT bi-plot drawn using PC 1 and 
PC 2 scores explained 53\% of total variation (Figure 4). Yan and Rajcan, 2002 had used GT bi-plot to identify superior cultivars after analyzing various yield components in soybean for six years and reported $52-63 \%$ of the total variation of the data among 28 soybean cultivars. They attributed this low proportion of variation to complex relationships among different traits similar to the ones observed in the present study. Further to study the relationships between different traits, a vector was drawn from origin to trait. The largest variation was explained by pod yield and other unsaturated fatty acids.

There was a strong positive relationship of pod yield with 100-seed weight, oil and protein contents as indicated by acute angle between vectors (Figure 4). Such positive association was observed when 504 accessions of peanut core collection for Asia (Upadhyaya and Ortiz, 2001) were analyzed for 21 different traits at two different locations by Mallikarjuna swamy et al., (2003). These 4 traits had negative association with SFA as indicated by obtuse angle between them. Interrelationships among the above traits are very important to breed confectionery grade peanut cultivars. Few important relationships exhibited by GT bi-plot in the present study were: (i) negative relation of oleic acid and O/L ratio with linoleic acid and SFA. Such a negative relation between oleic acid with linoleic acid and $\mathrm{O} / \mathrm{L}$ ratio with linoleic acid have already been reported in peanut (Dwivedi et al., 1993; Anderson et al., 1998; Singkham et al., 2010), (ii) the vectors of Oleic acid and O/L ratio were nearly perpendicular to that of oil content indicating a weak correlation. Thus it is possible to have genotypes with low oil and high $\mathrm{O} / \mathrm{L}$ ratio The above associations among different confectionery traits and also with yield indicates a possibility of selecting genotypes with complementary traits for breeding high yielding confectionery grade cultivars.

GT bi-plot can also be used to compare cultivars on the basis of multiple traits and to identify potential ones for using them in breeding programme. The Vertex cultivars were GPBD-4, S-230, M-28-2, JL-24, TMV-2, Dh-3-30. These cultivars were the best or the poorest for some or all of the traits, because they had the longest distance from the origin of the biplot (Yan et al., 2007). Cultivar S-230 was superior for oleic acid and O/L ratio whereas GPBD-4, M-28-2 and JL-24 were high yielders with high oil content.

\subsection{Morphological vs. molecular diversity}

UPGMA algorithm has been used to construct dendrogram of various qualitative and quantitative traits (Chowdhury et al., 2002; Ali et al., 2010; Seetharam et al., 2009). Hence in the present study UPGMA was used for grouping cultivars using various quantitative traits and molecular data. Grouping of cultivars into different clusters for quantitative traits followed a specific pattern wherein, for example cultivars included in cluster 2 (Table 5 and 1) were recommended for one or more states other than Karnataka. In cluster 3 most of the cultivars had either blood of Spanish improved or JL-24 in their pedigree (Badigannavar et al., 2002; Murty et al., 2004) whereas cultivars grouped in cluster 1 were mainly selections from germplasm accessions (Table 1). Varieties that were derived from hybridisation were more diverse than varieties, which were derived as result of selection from land races. Among the cross derivatives, varieties which were obtained as a result of use of exotic germplasm were more diverse than those derived from crossing between local genotypes.

Comparison of cultivar groupings by different methods are presented in Table 5. Interestingly, for quantitative traits groupings were almost similar by both PCA and UPGMA clustering with few exceptions. For example, cultivars K-134, KRG-1, Dh 3-30, S-206 and Spanish improved were clustered together in all three methods and were derived as selections (except K-134) from local cultivars. Cultivars ICGV-86590 and R-8808 were clustered together for quantitative traits and molecular data and they are derived through hybridization involving exotic germplasm as one of their parents. Based on quantitative data GPBD-4 was grouped with M-28-2. However, this grouping did not corroborate with grouping based on molecular data. Clustering by UPGMA method with RAPD data grouped three cultivars namely R-8808, GPBD-4 and ICGV-86590 into one group and the rest into other group. These three cultivars were derived through hybridization using germplasm lines or introduced material (Chico) as one of their parents. Cultivars S 230 and Spanish Improved derived as selections from germplasm were in different group as per quantitative traits, but at genetic level they were similar. As observed in the present study also very low diversity among cultivars at genetic level have been reported by using RAPD (Subramanian et al., 2000 ; Dwivedi et al., 2001), AFLP (Herselman, 2003) and SSR (Raina et al., 2001; Krishna et al., 2004) markers.

Multivariate analytical tools used in the present study were able to classify cultivars into different groups and also identified the clusters which could be used in breeding programme. It also identified traits which explained maximum variation like pod yield, saturated fatty acid, Oil content, Oleic acid and O/L ratio. Few desirable associations were also observed between yield, oil content, protein content, 100 -seed weight and saturated fatty acids. These associations can be utilized in breeding for location specific varieties with good confectionery qualities. 


\section{Acknowledgement}

The corresponding author would like to express profound gratitude to the team members for their invaluable support, encouragement and useful suggestions throughout this research.

\section{References}

Ali, A., Javed, B., Mohammad, R. N., \& Javed, A. (2010). Genetic diversity of Persian shallot (Allium hirtifolium) ecotypes based on morphological traits, allicin content and RAPD markers. Open Access Journal of Medicinal and Aromatic Plants, 1, 1-6.

AOCS. (1999). American Oil Chemists Society (AOCS)- Fatty Acid Composition by GLC Ce 1b-89 of 1999.

Anderson, P. C., Hill, K., Gorbet, D. W. \& Brodbeck, B. V. (1998). Fatty acid and amino acid profiles of selected peanut cultivars and breeding lines. Journal of Food Composition and Analysis, 11, 100-111. http://dx.doi.org/10.1006/jfca.1998.0565

Badigannavar, A. M., Kale, D. M. \& Murty, G. S. S. (2002). Genetic base and diversity in peanut genotypes. Plant Breeding, 121, 348-353. http://dx.doi.org/10.1046/j.1439-0523.2002.00710.x

Belamkar, V., Selvaraj, M. G., Ayers, J. L., Payton, P. R., Puppala, N. \& Burow, M.D. (2011). A first insight into population structure and linkage disequilibrium in the US peanut minicore collection. Genetica, [Epub ahead of print]. http://dx.doi.org/10.1007/s10709-011-9556-2

Chowdhury, A. K., Srinives, P., Tongpamnak, P., Saksoong, P. \& Chatwachirawong, P. (2002). Genetic relationship among exotic soybean introductions in Thailand: Consequence for varietal registration. ScienceAsia, 28, 227-239. http://dx.doi.org/10.2306/scienceasia1513-1874.2002.28.227

DAC (Department of Agriculture and Statistics) (2010). Agricultural statistics at glance. http://dacnet.nic.in/eands/latest_2006 accessed on 04/01/2011

Dwivedi, S. L., Nigam, S. N., Jambunathan, R., Sahrawat, K. L., Nagabhushanam, G. V. S. \& Ragunath, K. (1993). Effect of genotypes and environment on oil content (quality parameters and their correlation in peanut (Arachis hypogaea L.). Peanut Science, 20, 84-89. http://dx.doi.org/10.3146/i0095-3679-20-2-5

Dwivedi, S. L. \& Nigam, S. N. (1995). Breeding for improved seed quality in groundnut (A. hypogea L.) with special reference to export promotion: issues and opportunities, Paper presented at workshop on" Status of Confectionery Goundnut Research in India and Strategies for Export Promotion, BARC, Trombay, Mumbai. p.10.

Dwivedi, S. L., Gurtu, S., Charndra, S., Yuejin, W. \& Nigam, S. N. (2001). Assessment of genetic diversity among selected peanut germplasm RAPD Analysis. Plant Breeding, 120, 345-349. http://dx.doi.org/10.1046/j.1439-0523.2001.00613.x

FAO. (2009). Food and Agriculture Organization http://www.FAO.ORG/FAOSTAT database. accessed on $04 / 01 / 2011$.

Herselman, L. (2003). Genetic variation among Southern African cultivated peanut (Arachis hypogaea L.) genotypes as revealed by AFLP analysis. Euphytica, 133, 319-327. http://dx.doi.org/10.1023/A:1025769212187

Jambunathan, R. S., Raju, S. M. \& Shubhada, P. B. (1985). Analysis of oil content of groundnut by nuclear magnetic resonance spectrometry. Journal of the Science of Food and Agriculture, 36, 162-166. http://dx.doi.org/10.1002/jsfa.2740360306

Kannenberg, L. W. \& Falk, D. E. (1995). Models for activation of plant genetic resources for crop breeding programs. Canadian Journal of Plant Science, 75(1), 45-53. http://dx.doi.org/10.4141/cjps95-008

Kaiser, H. F. (1960). The application of electronic computers to factor analysis. Educational and Psychological Measurement, 20,141-151. http://dx.doi.org/10.1177/001316446002000116

Krishna, G. K., Jinfa, Z., Mark, B., Pitman, R. N., Delikostadinov, S. G., Yingzhi Lu, \& Naveen, P. (2004). Genetic diversity analysis in valencia peanut (Arachis hypogaea L.) using micro satellite markers. Cellular and Molecular Biology Letters, 9, 685-697.

Lowry, O. H., Rosebrough, N. J., Farr, A. L. \& Randall, R. J. (1951). Protein measurement with the Folin phenol reagent. Journal of Biological Chemistry, 193, 265-275.

Mallikarjuna Swamy, B. P., Upadhyaya, H. D., Kenchegowda, P. V., Kullaiswamy, B. Y. \& Singh, S. (2003). Phenotypic variation for agronomic characteristics in a groundnut core collection for Asia. Field Crops Research, 84, 359-371. http://dx.doi.org/10.1016/S0378-4290(03)00102-3 
Murty, G. S. S., Badigannavar, A. M., Mondal, S. \& Kale, D. M. (2004). Research and impact of groundnut mutation breeding in India. In: Groundnut Research in India. Directorate of Groundnut Research, Junagadh, Gujarat, India, p. 69.

Nagaraja Reddy, R., Parameshwarappa, K. G. \& Nadaf, H. L. (2004). Molecular diversity for resistance to late leaf spot and rust in parents and segregating population of a cross in groundnut. International Arachis Newsletter, 24, 31-33.

Nigam, S. N., Dwivedi, S. L., Reddy, L. J. \& Vasudeva rao, M. J. (1989). An update on groundnut breeding activites at ICRISAT centre with particular reference to breeding and selection for improved quality. Proceedings of the Third Regional Groundnut Workshop, held during 13-18 March 1988, Lilongwe, Malwi, pp. 115-25.

Okuno, K., Ebana, K., Noov, B. \& Yoshida, H. (1998). Genetic diversity of central Asian and North Caucasian Aegilops species as revealed by RAPD primers. Genetic Resources and Crop Evolution, 45, 389-394. http://dx.doi.org/10.1023/A:1008660001263

Pattanashetti, S.K. (2005). Genetic analysis of mutational origin of diversity in groundnut (Arachis hypogaea L.). $\mathrm{Ph}$. D. Thesis, University of Agricultural Sciences, Dharwad.

Pearson, K. (1901). On Lines and Planes of Closest Fit to Systems of Points in Space. Philosophical Magazine 2 (6): 559-572. http://stat.smmu.edu.cn/history/pearson1901.pdf.

Raina, S.N., Rani, V., Kojima, T., Ogihara, Y., Singh, K. P. \& Devrmath, R. M. (2001). RAPD and ISSR finger prints: an useful genetic markers for analysis of genetic diversity, varietal identification and phylogenetic relationships in peanut (Arachis hypogaea L.) cultivar and wild species. Genome, 44, 763-772.

Rajendraprasad. (2003). Genetic enhancement of host plant resistance to Spodoptera litura (Fab.) in groundnut. $\mathrm{Ph}$. D. Thesis, University of Agricultural Sciences, Dharwad.

Rohlf, F.J. (1998). NTSYSPC numerical taxonomy and multivarietal analysis, Version 2. 0. Applied Biostatics, New York.

SEA. (2010). The Solvent extractor's Association of India: In SEA Handbook 2009. http://www.seaofindia.com/

Seetharam, K., Thirumeni, S. \& Paramasivam, K. (2009). Estimation of genetic diversity in rice (Oryza sativa L.) genotypes using SSR markers and morphological characters. African Journal of Biotechnology, 8, 2050-2059.

Shilman, F., Brand, Y., Brand, A., Hedvat, I. \& Hovav, R. (2011). Identification and Molecular Characterization of Homeologous $\Delta 9$-Stearoyl Acyl Carrier Protein Desaturase 3 Genes from the Allotetraploid Peanut (Arachis hypogaea). Plant Molecular Biology Reporter, 29, 232-241. http://dx.doi.org/10.1007/s11105-010-0226-9

Singkham, N., Jogloy, S., Kesmala, T., Swatsitang, P., Jaisil, P., Puppala, N. \& Patanothai, A. (2010). Estimation of heritability by parent-offspring regression for high oleic acid in peanut. Asian Journal of Plant Sciences, 9 , 358-363. http://dx.doi.org/10.3923/ajps.2010.358.363

Sneath, P. H. A. \& Sokal, R. R. (1973). Numerical Taxonomy. WH Freeman. San Francisco. p.537.

Subramanian, V., Gurtu, S., Rao, R. C. N. \& Nigam, S. N. (2000). Identification of DNA polymorphism in cultivated groundnut using random amplified polymorphic DNA (RAPD) assay. Genome, 43, 656-660. http://dx.doi.org/10.1139/g00-034

Troyer, A.F. (1990). A retrospective view of corngenetic resources. Journal of Heredity, 81,17-24.

Upadhyaya, H.D, \& Ortiz, R. (2001). A mini core subset for capturing diversity and promoting utilization of chickpea genetic resources in crop improvement. Theoretical and Applied Genetics, 102, 1292-1298. http://dx.doi.org/10.1007/s00122-001-0556-y

Upadhyaya, H.D., Yadav, D., Dronavalli, N., Gowda, C. L. L. \& Singh, S. (2010). Mini core germplasm collections for infusing genetic diversity in plant breeding programs. Electronic Journal of Plant Breeding, 1(4), 1294-1309.

Vijay, V. (2003). Evaluation of resistance to Sclerotium rolfsii Sacc. in groundnut (Arachis hypogaea L.). M. Sc. (Agri.) Thesis, University of Agricultural Sciences, Dharwad.

Yan, W. \& Rajcan, J. (2002). Biplot Analysis of Test Sites and Trait Relations of Soybean in Ontario. Crop Science, 42, 11-20. http://dx.doi.org/10.2135/cropsci2002.0011

Yan, W., Kang, M. S., Ma, B., Woods, S. \& Cornelius, P. L. (2007). GGE biplot vs. AMMI analysis of genotype-by environment data. Crop Science, 47, 643-653. http://dx.doi.org/10.2135/cropsci2006.06.0374 
Table 1. Information on pedigree of location specific and broad based peanut genotypes of India

\begin{tabular}{|c|c|c|c|c|}
\hline Variety & Botanical group & Pedigree & Release & $\begin{array}{c}\text { Area for which } \\
\text { released }\end{array}$ \\
\hline TMV 2 & Spanish Bunch & $\begin{array}{l}\text { Mass Selection From } \\
\text { Gudhiatham Bunch }\end{array}$ & 1940 & $\begin{array}{l}\text { Tamil Nadu, Andhra } \\
\text { Pradesh and Karnataka }\end{array}$ \\
\hline $\begin{array}{l}\text { Spanish } \\
\text { Improved }\end{array}$ & Spanish Bunch & Selection From Spanish Peanut & 1905 & $\begin{array}{l}\text { Bombay -Karnataka } \\
\text { Region }\end{array}$ \\
\hline S 206 & Spanish Bunch & Selection From 'Manvi Local' & 1969 & Karnataka \\
\hline S 230 & Virginia runner & Selection From Tandur Local & 1969 & Karnataka \\
\hline Dh 3-30 & Spanish Bunch & Spanish Improved' × 'US 4' & 1975 & Karnataka \\
\hline JL 24 & Spanish Bunch & Selection From 'EC 94943' & 1978 & $\begin{array}{l}\text { Maharashtra and } \\
\text { Gujarat but adopted to } \\
\text { entire country }\end{array}$ \\
\hline KRG 1 & Spanish Bunch & $\begin{array}{l}\text { Selection From 'Argentina } \\
\text { Variety' }\end{array}$ & 1981 & Karnataka \\
\hline Dh 8 & Spanish Bunch & Selection From 'RS 144' & 1984 & Karnataka \\
\hline TAG 24 & Spanish Bunch & TGS $2 \times$ TGE 1 & 1992 & Maharashtra. \\
\hline K 134 & Spanish Bunch & Kadari $3 \times$ JL 24 & 1996 & $\begin{array}{l}\text { Andhra Pradesh and } \\
\text { Tamil Nadu }\end{array}$ \\
\hline Dh 43 & Virginia runner & Selection From Mardur Local & 1997 & Karnataka \\
\hline R 8808 & Spanish Bunch & ICGS $11 \times$ Chico & 1997 & $\begin{array}{l}\text { Karnataka, Andhra } \\
\text { Pradesh and Tamil } \\
\text { Nadu }\end{array}$ \\
\hline R 9251 & Spanish Bunch & BARCG $1 \times$ TG23 & 1998 & Karnataka \\
\hline Dh 40 & Spanish Bunch & Dh3-30 $\times$ TGE2 & - & Karnataka \\
\hline $\begin{array}{l}\text { ICGV } \\
86590\end{array}$ & Spanish Bunch & X14-4-B-19b $\times$ pi259747 & 1996 & Peninsular India \\
\hline $\begin{array}{l}\text { Mutant } \\
28-2\end{array}$ & Spanish Bunch & $\begin{array}{l}\text { EMS Treated Mutant Derived } \\
\text { From VL-1 }\end{array}$ & 2002 & Karnataka \\
\hline GPBD 4 & Spanish Bunch & KRG $1 \times$ ICGV 86855 & 2002 & $\begin{array}{l}\text { Southern and eastern } \\
\text { India }\end{array}$ \\
\hline
\end{tabular}

Table 2. Mean and variance for different quantitative characters among different clusters obtained through UPGMA

\begin{tabular}{|l|c|c|c|c|c|c|}
\hline \multirow{2}{*}{ Traits } & \multicolumn{3}{|c|}{ Mean } & \multicolumn{3}{c|}{ Variance } \\
\cline { 2 - 7 } & Cluster 1 & Cluster 2 & Cluster 3 & Cluster 1 & Cluster 2 & Cluster 3 \\
\hline PYL & 14.55 & 12.60 & 11.58 & 8.50 & 13.03 & 39.89 \\
\hline TWT & 43.82 & 30.43 & 39.52 & 43.36 & 10.06 & 51.81 \\
\hline OIL & 44.70 & 42.63 & 44.81 & 13.89 & 2.53 & 10.27 \\
\hline PRO & 25.86 & 28.11 & 27.89 & 4.41 & 6.31 & 14.40 \\
\hline DFF & 43.33 & 42.00 & 44.25 & 2.67 & 4.80 & 13.58 \\
\hline LL & 6.19 & 6.35 & 4.83 & 0.16 & 0.18 & 0.34 \\
\hline LW & 3.18 & 3.30 & 2.77 & 0.05 & 0.01 & 0.07 \\
\hline PRI & 7.27 & 5.55 & 6.17 & 3.63 & 0.80 & 4.04 \\
\hline SEC & 2.11 & 0.33 & 3.58 & 11.28 & 0.27 & 14.59 \\
\hline PHT & 33.16 & 36.96 & 26.81 & 4.24 & 1.80 & 96.94 \\
\hline PAL & 12.55 & 14.50 & 10.74 & 0.06 & 3.39 & 0.39 \\
\hline STE & 2.16 & 4.74 & 2.36 & 0.81 & 6.67 & 0.08 \\
\hline OLE & 37.84 & 36.94 & 48.55 & 1.27 & 3.21 & 26.89 \\
\hline LIN & 38.76 & 38.18 & 31.77 & 0.84 & 8.82 & 18.40 \\
\hline OTH & 8.20 & 5.44 & 6.62 & 3.14 & 8.09 & 8.02 \\
\hline SFA & 14.72 & 19.24 & 13.10 & 1.10 & 3.11 & 0.39 \\
\hline O/L & 0.97 & 0.97 & 1.57 & 0.00 & 0.01 & 0.13 \\
\hline
\end{tabular}

PYL $=$ pod yield per plant $(\mathrm{g}) ; \mathrm{TWT}=100$-seed weight; OIL $=$ Oil content $(\%) ; \mathrm{PRO}=$ Protein content $(\%)$; $\mathrm{LL}=$ leaf length; LW = Leaf width; PRI = Primary branches per plant; SEC $=$ Secondary branches per plant; PHT $=$ plant height $(\mathrm{cm}) ; \mathrm{PAL}=$ Palmitic acid $(\%)$; STE $=$ Stearic acid $(\%) ;$ OLE $=$ Oleic acid $(\%)$;

LIN = Linoleic acid; OTH = Other Fatty acid (\%); SFA = Saturated fatty acid; O/L = Oleic / Linoleic acid ratio 
Table 3. PCA components for different quantitative characters in 17 peanut genotypes

\begin{tabular}{|l|c|c|c|c|c|}
\hline PC & 1 & 2 & 3 & 4 & 5 \\
\hline Eigen value & 5.90 & 3.16 & 2.32 & 1.60 & 1.27 \\
\hline \% variance & 34.74 & 18.60 & 13.64 & 9.43 & 7.45 \\
\hline cumulative variance & 34.74 & 53.33 & 66.97 & 76.40 & 83.84 \\
\hline \multicolumn{6}{|c|}{ Loadings } \\
\hline PYL & -0.20 & 0.91 & -0.12 & 0.08 & -0.17 \\
\hline TWT & 0.46 & 0.53 & -0.07 & -0.02 & 0.58 \\
\hline OIL & 0.29 & 0.69 & -0.16 & 0.11 & 0.06 \\
\hline PRO & -0.16 & 0.17 & -0.22 & 0.70 & -0.48 \\
\hline DFF & 0.60 & -0.40 & -0.06 & -0.31 & 0.37 \\
\hline LL & -0.71 & 0.37 & -0.42 & -0.20 & 0.29 \\
\hline LW & -0.76 & 0.26 & -0.08 & -0.30 & -0.03 \\
\hline PRI & 0.04 & 0.23 & 0.84 & -0.34 & -0.17 \\
\hline SEC & 0.50 & -0.19 & 0.26 & 0.37 & 0.27 \\
\hline PHT & -0.50 & 0.14 & -0.67 & 0.18 & 0.33 \\
\hline PAL & -0.85 & -0.26 & 0.07 & 0.30 & 0.08 \\
\hline STE & -0.38 & -0.33 & -0.38 & -0.55 & -0.23 \\
\hline OLE & 0.90 & -0.10 & -0.34 & 0.04 & -0.12 \\
\hline LIN & -0.74 & -0.03 & 0.53 & 0.26 & 0.29 \\
\hline OTH & 0.13 & 0.85 & 0.17 & -0.31 & -0.16 \\
\hline SFA & -0.80 & -0.40 & -0.21 & -0.18 & -0.11 \\
\hline O/L & 0.84 & -0.10 & -0.44 & -0.06 & -0.20 \\
\hline
\end{tabular}

Table 4. Analysis of RAPD banding pattern among 17 peanut cultivars

\begin{tabular}{|l|c|c|c|}
\hline Primer & $\begin{array}{c}\text { No of amplified } \\
\text { bands }\end{array}$ & $\begin{array}{c}\text { No of polymorphic } \\
\text { bands }\end{array}$ & $\begin{array}{c}\text { Per cent } \\
\text { polymorphism }\end{array}$ \\
\hline OPA 12 & 5 & 5 & 100 \\
\hline OPA 15 & 2 & 0 & 0 \\
\hline OPA 17 & 5 & 3 & 60 \\
\hline OPA 19 & 6 & 5 & 83 \\
\hline OPA 20 & 6 & 3 & 50 \\
\hline OPB 11 & 1 & 0 & 0 \\
\hline OPC 03 & 8 & 8 & 100 \\
\hline OPC 06 & 6 & 2 & 30 \\
\hline OPC 09 & 11 & 7 & 64 \\
\hline OPC 13 & 9 & 9 & 100 \\
\hline OPC 15 & 15 & 14 & 93 \\
\hline OPF 07 & 7 & 3 & 43 \\
\hline OPF 09 & 7 & 3 & 43 \\
\hline OPF 10 & 10 & 7 & 70 \\
\hline OPJ 06 & 9 & 8 & 89 \\
\hline OPJ17 & 8 & 5 & 62.5 \\
\hline OPK 09 & 7 & 3 & 43 \\
\hline OPK 14 & 7 & 5 & 64 \\
\hline OPV 15 & 11 & 7 & 40 \\
\hline OPV 16 & 5 & 2 & -- \\
\hline Total & 145 & 99 & 68.28 \\
\hline Average & 7.25 & 4.95 & \\
\hline & & & 71 \\
\hline
\end{tabular}


Table 5. Grouping of 17 peanut cultivars by different clustering methods

\begin{tabular}{|c|c|c|c|}
\hline \multirow[b]{2}{*}{ Group } & \multicolumn{2}{|c|}{ quantitative traits } & \multirow{2}{*}{$\begin{array}{l}\text { Molecular } \\
\text { UPGMA }\end{array}$} \\
\hline & UPGMA clustering & PCA clustering & \\
\hline Cluster 1 & $\begin{array}{l}\text { JL-24, M-28-2, R-8808, } \\
\text { ICGV 86590, Dh } 40 \text { and } \\
\text { TAG } 24\end{array}$ & GPBD-4 and M-28-2 & $\begin{array}{l}\text { TMV-2, Spanish improved, } \\
\text { S-206, Dh-3-30, K-134, } \\
\text { KRG-1, Dh-8, TAG-24, } \\
\text { Dh-43, R -9251, DH-40, } \\
\text { M-28-2, JL-24 }\end{array}$ \\
\hline Cluster 2 & $\begin{array}{l}\text { Spanish improved, } \\
\text { Dh-3-30, S-206, KRG-1, } \\
\text { K-134 and TMV-2 }\end{array}$ & JL-24 and TMV-2 & $\begin{array}{l}\text { R-8808, GPBD-4, } \\
\text { ICGV-86590 }\end{array}$ \\
\hline Cluster 3 & $\begin{array}{l}\text { S-230, Dh- } 43, \text { Dh- } 8 \text { and } \\
\text { GPBD } 4\end{array}$ & $\begin{array}{l}\text { Dh-3-30, K-134, KRG-1, } \\
\text { R-9251, Spanish } \\
\text { improved and S-206, }\end{array}$ & \\
\hline Cluster 4 & R-9251 & Dh-8, Dh-43 & \\
\hline Cluster 5 & & $\begin{array}{l}\text { ICGV-86590, R-8808, } \\
\text { Dh-40 and TAG-24 }\end{array}$ & \\
\hline
\end{tabular}

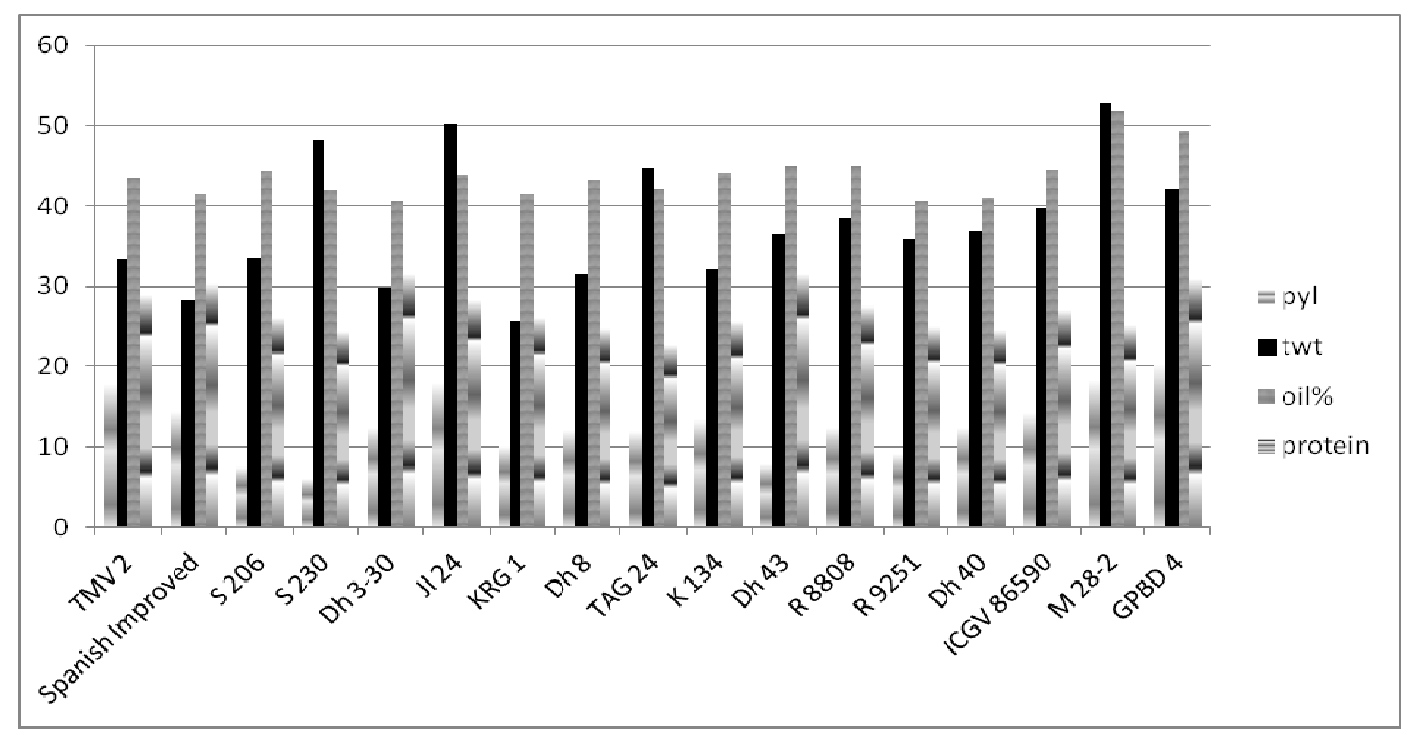

Figure 1. Performance of groundnut varieties for pod yield (pyl), 100-seed weight (twt), oil and protein content

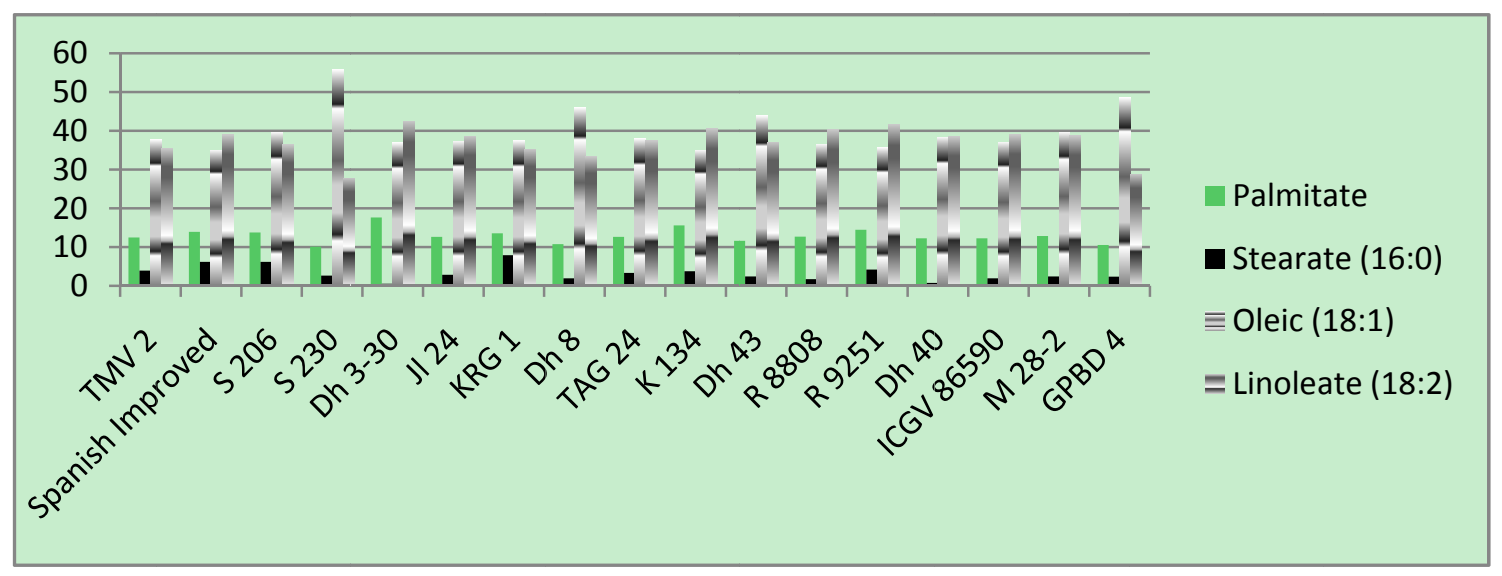

Figure 2. Performance of groundnut varieties for fatty acid profile 


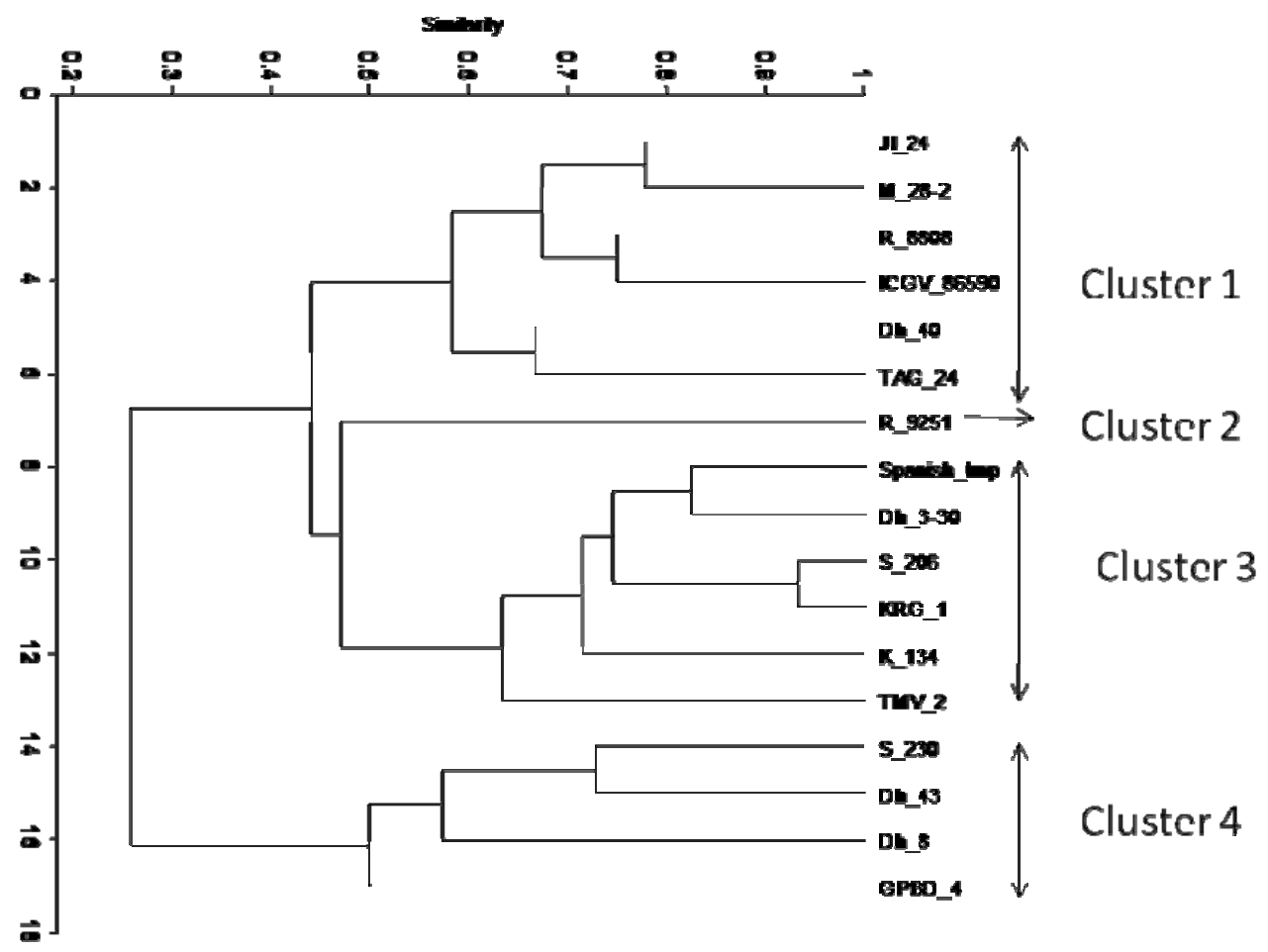

Figure 3. Cluster analysis of 17 peanut genotypes based on quantitative and confectionery traits

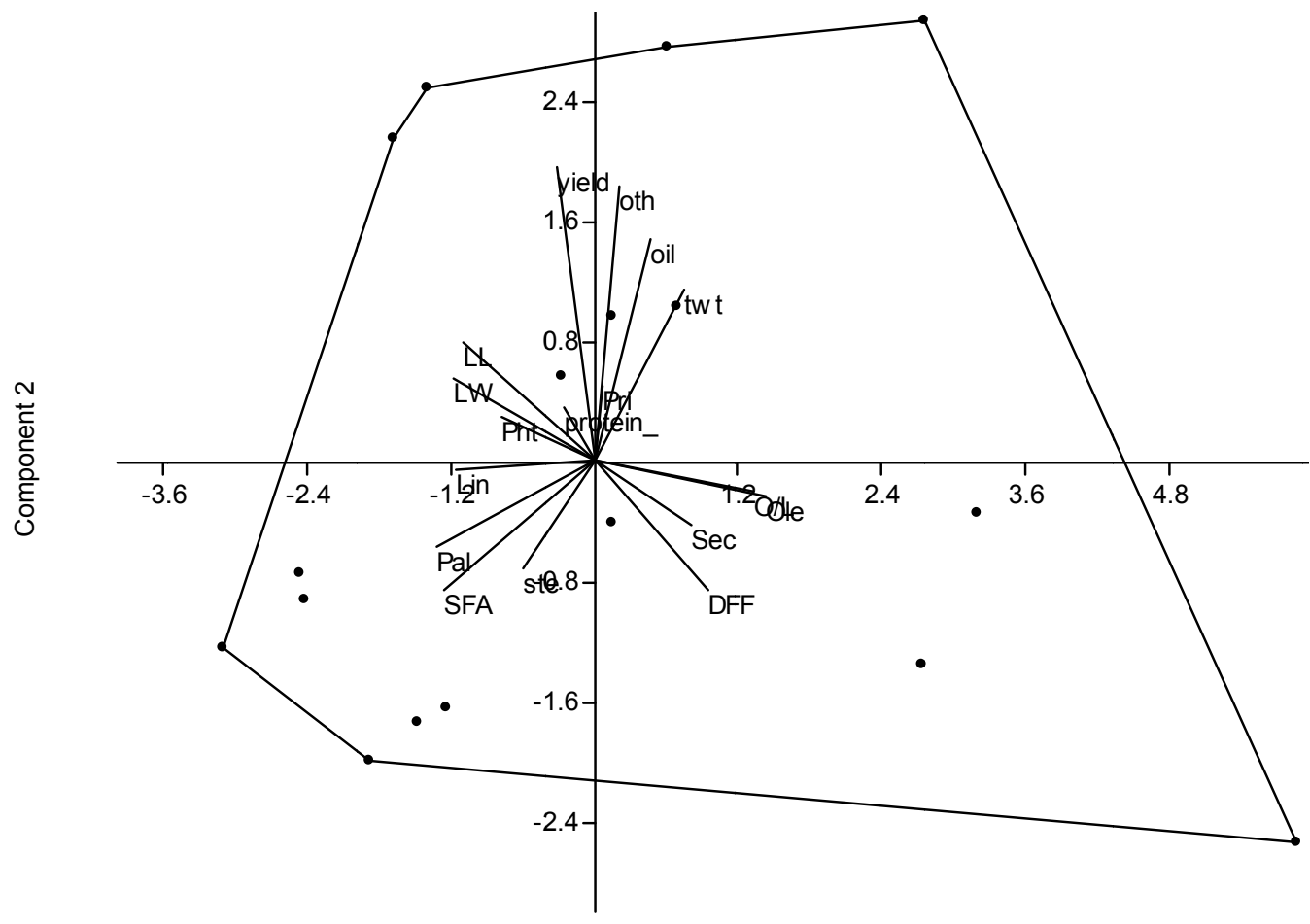

Component 1

Figure 4. Bi-plot of 17 peanut cultivars for different quantitative and confectionery characters

Yield $=$ pod yield per plant $(\mathrm{g}) ; \mathrm{TWT}=100$-seed weight; $\mathrm{OIL}=$ Oil content $(\%)$; Protein $=$ Protein content $(\%)$; DFF $=$ days to $50 \%$ flowering; $\mathrm{LL}=$ leaf length; $\mathrm{LW}=$ Leaf width; $\mathrm{PRI}=$ Primary branches per plant; SEC = Secondary branches per plant; PHT = plant height $(\mathrm{cm}) ; \mathrm{PAL}=$ Palmitic acid $(\%) ; \mathrm{STE}=$ Stearic acid $(\%) ;$ OLE = Oleic acid (\%); LIN = Linoleic acid; OTH = Other Fatty acid (\%); SFA = Saturated fatty acid; O/L = Oleic / Linoleic acid ratio. 


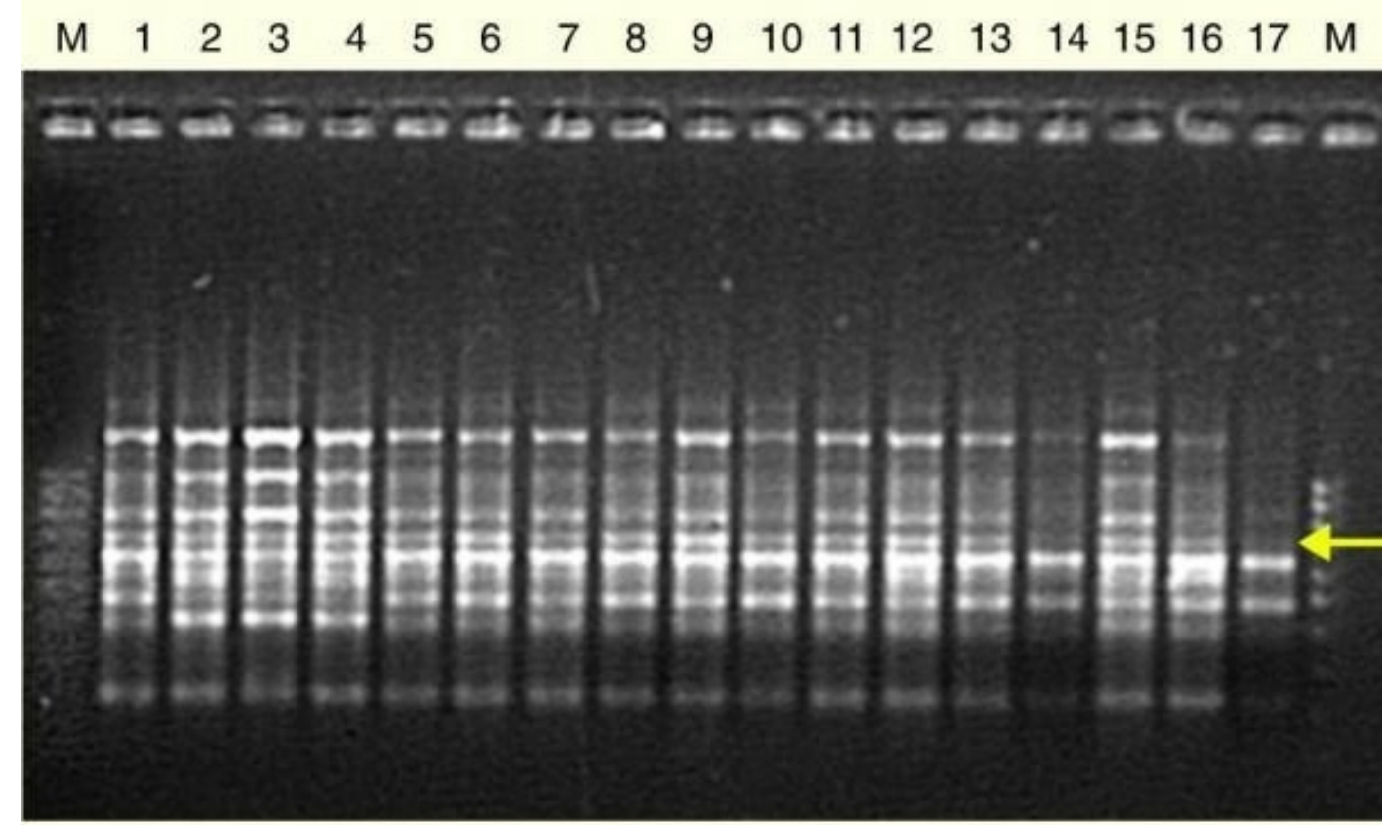

\section{OPV-15}

Figure 5. RAPD banding patterns in groundnut varieties

M : 100 bp ladder 1. JL-24, 2. TAG-24, 3. Mutant 28-2, 4. TMV-2, 5. R-9251, 6. KRG-1, 7. DH 3-30, 8. Dh-8, 9. S-206, 10. S-230, 11. Spanish improved, 12. K-134 13. Dh-43 14. Dh-40, 15. R-8808 16. GPBD-4 17. ICGV-86580

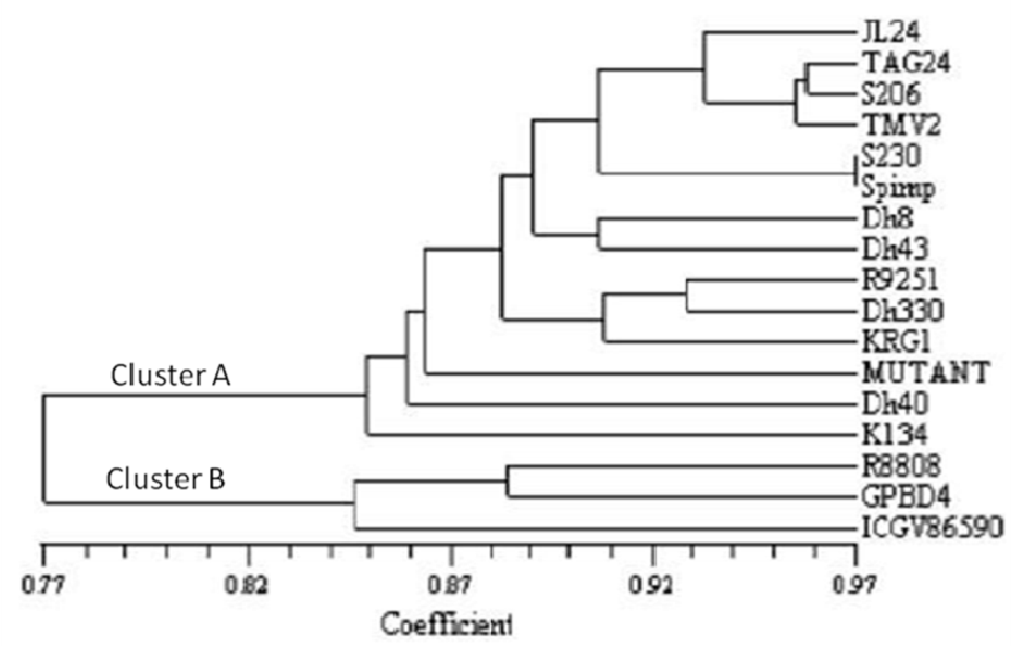

Figure 6. Dendrogram depicting genetic diversity in 17 peanut cultivars by using UPGMA 